\title{
Muslim Legal Thought in Modern Indonesia
}

\author{
R. Michael Feener \\ Cambridge, UK: Cambridge University Press, 2007. hbk. 270 pages.
}

Although it is the most populous country in the Muslim world, Indonesia has long been overlooked in scholarly discussions of modern Muslim legal thought. This neglect has been compounded by the fact that western scholarship on this Southeast Asian country has been dominated by historians, anthropologists, and political scientists rather than scholars conversant with the Islamic sciences. Since the mid-1990s this situation has begun to change, however, as a new generation of scholars trained in classical and modern Islamic scholarship have come on the scene. These young researchers have made Islamic thought in Indonesia available to a global English-language readership for the first time.

Fluent in Arabic as well as Indonesian, R. Michael Feener has established himself as among the most important members of this new generation of students of Indonesian Islam. The present book, a significant revision, updating, and expansion of his 1999 dissertation, seeks to provide a "road map" of "major trends in Indonesian Muslim thought on issues of law and society" (p. xvii) by focusing on the intellectual currents from the 1920s to the early 2000s. The author argues, correctly I believe, that this effort is significant not just because Muslim thought in Indonesia has yet to receive the attention it deserves, but because "Indonesia has become arguably the world's most vibrant center for contemporary Islamic thought" (p. 225).

The book opens with a brief but incisive discussion of how, during the first years of the twentieth century, new technologies of transportation, print, education, and association undermined traditional religious authority in Muslim Southeast Asia. Indigenous traditions of religious scholarship in Arabic as well as Malay, Javanese, and other local languages were well established by this time, but the arrival of "new group" (kaum muda) reformists led to the promulgation of new approaches to the Qur'an, the Sunnah, and fiqh. The only item missing in this otherwise thoughtful chapter is a discussion of the perspective of Islamic reform on the myriad non-Sunni Islams still common across Muslim Southeast Asia at this time.

In chapter 2, the author examines how cultural modernization and Islamic reform led to a "new, more broad-based interest in the study of $u s ̣ \bar{u} l$ and the pursuit of ijtihad' (p. 25) in voluntary organizations like the Persatuan Islam (Islamic Unity; PERSIS). Never shying away from polemics 
with fellow Muslims, PERSIS leaders brought the technical details of Islamic jurisprudence into public debates and thus "away from the monopolistic control formerly wielded by the formally trained 'ulama" (p. 27). PERSIS' contribution to the creation of an Islamic public sphere opened the way for the authors at the center of discussion in chapter 3, Hasbi Ash Shiddieqy and Hazairin. Although Hasbi was a specialist of fiqh and Hazairin specialized in customary law, the two agreed in advocating a fiqh adjusted to the realities of modern Indonesia. Their appeal was adopted and elaborated upon by scholars in the 1980s and 1990s.

Neither Hasbi nor Hazairin questioned the basis of the Indonesian state: its nationalist affirmation of the "Five Principles" (Pancasila). In chapter 4, one of the book's most riveting, Feener looks at authors who mounted just such a challenge. The central player in this escalating effort was the brilliant Sumatran-born reformist Muhammad Natsir. Drawn in his youth to PERSIS, Natsir served as the country's prime minister in the early 1950s, counting Christians and democratic socialists among his supporters. As his party's rivalry with the massive Communist party intensified, and as President Sukarno veered leftward, however, Natsir's commitment to pluralist democracy faltered. In 1957 he rejected Pancasila and called for the establishment of an Islamic state. Feener observes that his understanding of democracy had always been "pure majoritarianism" (p. 89) and thus unconcerned with questions of minority rights. Equally important, Feener argues, Natsir's understanding of Islamic law was compromised by his insistence that it should be "simplified" rather than critically reelaborated (p. 87). A similar spirit carried over into the organization he founded, the Dewan Dakwah Islamiyah Indonesia, which has consistently argued that any concern for new fiqh methologies is a dangerous distraction from the aims of Islamic unity and political struggle.

Under Indonesia's developmentalist New Order regime (1966-98), the country witnessed the expansion of a new middle class and forward-looking Islamic universities. The country also underwent a vast Islamic resurgence. In chapter 5, Feener demonstrates that these trends contributed to the emergence of a new class of Muslim intellectuals concerned with opening Indonesian Muslim learning to western science, Middle Eastern scholarship, and the challenge of modern governance. No less important, the trends revitalized the country's vast network of Islamic boarding schools (pesantren, pon$d o k$ ), the focus of chapter 6 . The revitalization of traditionalist education gave rise to classically trained scholars equally at ease with questions of accountable government as well as with classical jurisprudence. 
In the book's last substantive chapter, Feener examines some of the intellectual currents that have emerged in Indonesia since the country began its still-fragile transition to democracy. Although he devotes some paragraphs to radical Islamists, this is arguably the only chapter in this fine book that fails to achieve a representative balance of Islamic voices. The chapter makes only passing reference to the intellectual horizons of the Islamist militias that emerged in the post-Soeharto period. Although the country's elections have demonstrated that radicals enjoy limited support, the militants have used their superior organization and members' dedication to achieve an influence disproportionate to their numbers in society.

This small omission does not detract from this book's overall achievement. This work offers the finest account ever published of Indonesian Muslim thought. No less impressive, the author's discussion abounds with insights relevant for students of Islamic legal and political scholarship in other societies. The book is a welcome contribution to the study of Indonesian Islam and should be read by anyone interested in the modern refiguration of Muslim social thought. 